\title{
THE THREAD-LEAF SUNDEWS DROSERA FILIFORMIS AND DROSERA TRACYI
}

Barry A. Rice - Center for Plant Diversity - University of California - One Shields Avenue - Davis, California $95616 \cdot$ USA • bamrice@ ucdavis.edu

Keywords: Taxonomy: Drosera filiformis, D rosera tracyi.

Received: 12 J une 2010

\section{Introduction}

The thread-leaf sundews of the Eastern N orth A merica are spectacular plants with erect, tall, filiform leaves. B acklit in the morning or evening light, their leaves burst with sunlight. There are two thread-leaf sundews (also known as dew-threads), known as either infraspecific taxa within Drosera filiformis, or as Drosera filiformis and D rosera tracyi. In this paper, I review their history of discovery, the details of their ranges, and the arguments regarding whether the two taxa should be treated as one species or two. I also describe the morphological differences between the two sundews. In total, this paper summarizes the current knowledge for this group, and al so serves as a progress report on my continuing work on these plants.

\section{A history of controversy}

In 1808, Rafinesque described the thread-leaf sundew, D rosera filiformis Raf., which occurs on the A tlantic C oast of N orth A merica. The 1802 holotype he selected for this description is one of the ol dest N orth A merican herbarium specimens housed in a N orth A merican herbarium (Sheviak 2010). In 1906, Diels noted that specimens from the USA's Gulf Coast were larger and greener, so he established for them the name D. filiformis var. tracyi Diels. In doing so, the name D. filiformis Raf. var. filiformis was created automatically (i.e., an autonym) for the smaller, reddish thread-leaf sundew.

Diels obtained the varietal epithet "tracyi" from J.M. M acfarlane, who felt that the Gulf Coast plant should be treated as a new species ("D. tracyi"). W hile Diels disagreed, he did M acfarlane the courtesy of using his epithet, and even decorously noted "M acfarlane msc. sub titulo speciei" in the description for D. filiformis var. tracyi Diels. Schnell (2002) interpreted this L atin phrase to indicate that $\mathrm{M}$ acfarlane had an as-yet unpublished manuscript describing the plant as a new species- or at least intended to write such a manuscript!

Good intentions perhaps, but M acfarlane did not actually publish the name D rosera tracyi until his treatment of D rosera in B ailey's "The Standard Cyclopedia of H orticulture" (M acfarlane 1914; page 1077). Schnell (2002) argued that this publication did not constitute effective publication of the name "D. tracyi" because it was not accompanied by a $L$ atin description. (The only L atin description for the plant was published by Diels, in the treatment for "D rosera filiformis var. tracyi." However, $M$ acfarlane did not refer to the Diels description.) However, the L atin description requirement- as described by the ICBN (A rticle 36.1) - only applies to names described on or after $1 \mathrm{~J}$ anuary 1935. Therefore, D. tracyi M acf. is entirely valid for those who wish to use it.

Thirty years later, Frances Wynne noted that the sundews in eastern N orth A merican have distinct seeds shapes and surface characteristics (Wynne 1944). Since the seeds of the two thread-leaf 
sundews were identical, she followed Diels' perspective and treated them as two varieties of the same species. (She also established the name "D. filiformis var. typica," but this is a superfluous synonym for D. filiformis Raf. var. filiformis and should not be used.)

In the sixty-five years since Wynne's work, authorities have continued to disagree on whether to treat the thread-leaf sundews as one species or two. Gleason \& Cronquist (1991) do not even recognize the two sundews as separate at the varietal level. ( 0 ddly, the geographic distribution they describe for " $D$. filiformis" combines the range for both thread-leaf sundews, but their species description only fits the northern taxon's morphology and size.) Scientists who treat the thread-leaf sundews as varieties of one species include Kartesz (1994), Schnell (2002), and Schlauer (2002). M eanwhile authorities who treat them as two species include Clewell (1985), Godfrey \& Wooten (1981), L. M ellichamp (pers. comm., 2010), and Sorrie (1998). Overall, in the last decade the twospecies perspective has become dominant in floristic works- examples include The Biota of N orth A merica Program (BONA P.org), the Flora of N orth A merica (fna.org), The Flora of the Southern and M id-A tlantic States (Weakley 2010), and NatureServe (N atureServe.org). Within the world of carnivorous plant enthusiasts, the tradition has typically been to follow the single-species perspective ${ }^{1}$.

M olecular studies have been illuminating many aspects of D rosera phylogeny (Rivadavia et al. 2003), but they have not been applied to the matter of the thread-leaf sundews, and even if they were, would be unlikely to reveal much regarding these two closely related taxa.

M y own perspectives of the two sundews have evolved over time. I long used the single-species approach (Rice 2006), but my interest in the Floridian "red" D. filiformis has caused me to revisit this carefully and in depth. After much consideration on this matter, I have switched to the two-species perspective. For simplicity, the rest of this paper will be presented using the two-species nomenclature.

\section{The ranges of D rosera tracyi and D. filiformis}

D rosera tracyi is native to an ever-shrinking range in the USA's Gulf Coast states (Figure 1). $M$ uch of its quoted habitat range is now purely of historical interest. Ranges below are based upon collections made or confirmed within the last ten years.

Florida: This state contains the bulk of the species' range. Drosera tracyi has been collected in every county of the panhandle (i.e., the narrow, western extension of the state), from Wakulla and Leon Counties westward, with the apparent exception of Gadsen County (Sorrie 1998; W underlin $\&$ Hansen 2008).

Georgia: It was formerly known from Brooks, Calhoun, Cook, Grady, Lowndes, Thomas, and Worth Counties, but is apparently now extinct in them all (NatureServe 2008; Sorrie 1998). It is now only known from Colquitt County. Since it is known from only five or fewer occurrences in the state, it is considered critically imperiled by the Georgia Department of $\mathrm{N}$ atural Resources.

Alabama: It has been collected from Mobile, Baldwin, Washington, Escambia, and Covington Counties (BONAP 2010; Sorrie 1998; USDA 2010).

M ississippi: K nown from H ancock, Harrison, Jackson, Stone, George, and Perry Counties (B O NA P 2010; Sorrie 1998; USDA 2010).

L ouisiana: A single poorly documented collection was made in 1907, putatively from an unspecified parish in Louisiana; if this information is correct, the plant is probably from St. Tammany or Washington Parish (Sorrie 1998). The Louisiana Natural Heritage Program tracks this species in

\footnotetext{
${ }^{1}$ This is no doubt at least partly because of the considerable authority and prominence Schnell has had with this audience. He was editor of Carnivorous Plant Newsletter from its inception to 1996.
} 


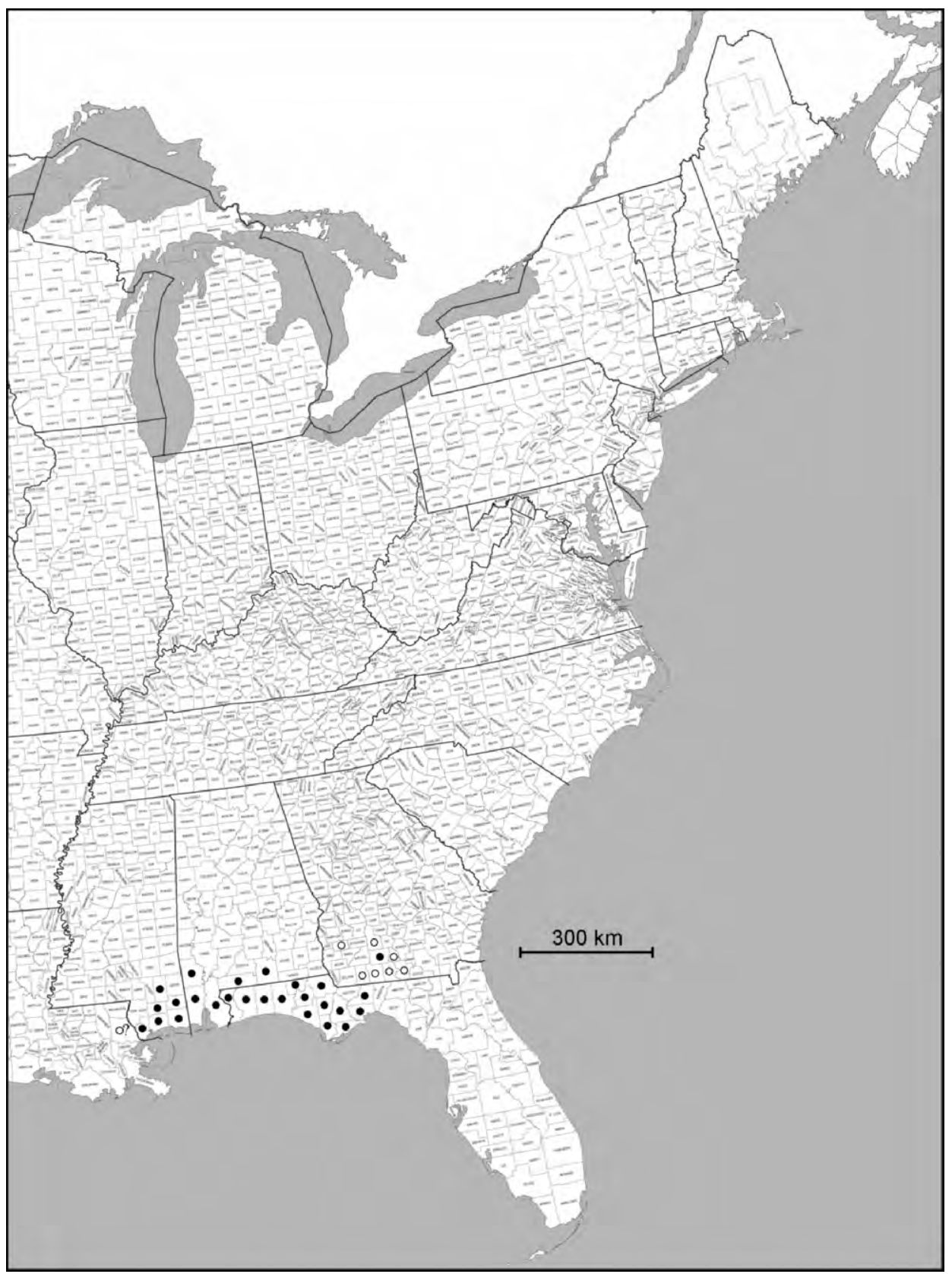

Figure 1: A 2010 snapshot of the range of Drosera tracyi. Counties or parishes believed to currently maintain native populations are indicated by a black dot. Counties where it is believed $D$. tracyi has been extirpated are indicated by an empty circle. The question mark for the Louisiana site notes that it has not been confirmed that Drosera tracyi has ever occurred there. 
their databases as a plant from St. Tammany Parish, but considers it to be presumably extinct in the state (L N HP 1999).

South C arolina: Reports in the literature for this plant in this state (e.g., Wynne 1944) do not seem to be supported by voucher specimens.

Other sites: Drosera tracyi has been planted by horticulturists in California (M endocino County). No doubt exotic plantings occur elsewhere in North A merica and around the world.

D rosera filiformis has a range which is strikingly different from that of $D$. tracyi for two reasons. First, instead of being strictly a USA Gulf Coast plant, it occurs primarily along the A tlantic Coast of $\mathrm{N}$ orth A merica (Figure 2). Second, instead of being largely continuous, its range is divided into four greatly separated segments: N ova Scotia (Canada), USA mid-A tlantic states, N orth Carolina, and Florida. The Nova Scotia range segment is only $20 \mathrm{~km}$ long. The mid-A tlantic range segment is $450 \mathrm{~km}$ southwest of the N ova Scotia sites, and spans more than $600 \mathrm{~km}$ of the A tlantic Coast. A pproximately $450 \mathrm{~km}$ separates the mid-A tlantic range segment from the N orth Carolina segment, which itself is approximately $140 \mathrm{~km}$ in extent (county edge to county edge). Finally, $850 \mathrm{~km}$ separates the N orth Carolina segment from the Florida populations- a cluster of sites only $20 \mathrm{~km}$ across.

U nfortunately, the range of $D$. filiformis, like that of $D$. tracyi, is decreasing rapidly in extent and quality.

\section{Canada Range Segment}

Nova Scotia (C anada): D rosera filiformis was discovered in 1977 in Shelburne County (Sorrie 1998); peat studies indicate it has grown there for at least 4240 years ( $L$ andry \& C wynar 2005). B ecause of its great rarity - it is only known from five locations- it has been declared an endangered species by government agencies in both Nova Scotia and Canada (COSEW IC 1991; NSSRW G 2000). In fact, the presence of $D$. filiformis prevented one bog from being turned into a peat mining operation (Landry \& Cwynar 2005).

\section{USA M id-A tlantic R ange Segment}

M assachusetts: It has been found in Plymouth, B arnstable, N antucket, and Dukes Counties (Sorrie 1998; USDA 2010), although it is extinct at many of its former sites in the state.

Rhode I sland: A single small population was recorded for Washington County in 1977, but it apparently dwindled to extinction around 1990 (Enser 2007; Sorrie 1998). It has been theorized (Sorrie 1998) that the populations in R hode Island and $M$ assachusetts might be short-term in nature- as new sites are opened by disturbance, $D$. filiformis propagules from other states may invade until the site becomes overgrown. Sorrie's suggestion of wind dispersal from the nearby $(<150 \mathrm{~km}) \mathrm{New}$ York populations seems less likely than transport by waterfow I from $\mathrm{N}$ ew York or M assachusetts. If this dispersal theory is correct, the natural human tendency to fragment habitat and prevent natural succession processes suggests that $D$. filiformis is unlikely to reestablish itself in R hode Island and M assachusetts.

Connecticut: It has been found in N ew London and Hartford Counties, but these populations are probably extinct because of habitat change (Sorrie 1998). It is listed in Connecticut as a "probably extirpated" plant of Special Concern by the Connecticut Department of Environmental Protection (ct.gov/dep).

New York: It occurs only in Suffolk County on L ong Island, and as such it is on the state's Rare Plant List (Sorrie 1998; Young 2010). Fortunately, at least one site is owned and protected by The $\mathrm{N}$ ature Conservancy (nature.org). 


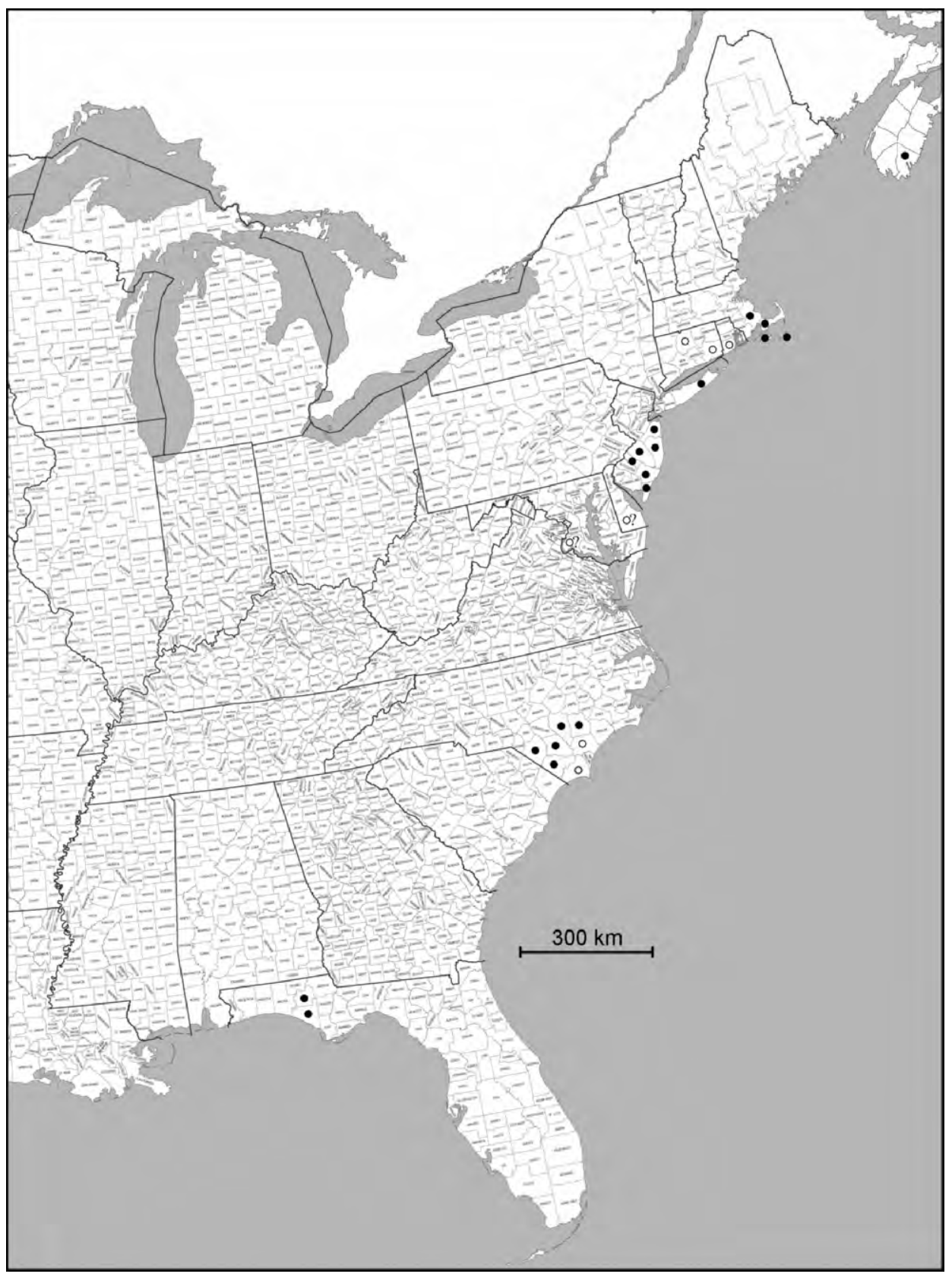

Figure 2: A 2010 snapshot of the range of Drosera filiformis. Counties believed to currently maintain native populations are indicated by a black dot. Counties where it is believed D. filiformis has been extirpated are indicated by an empty circle. Only native sites have been plotted. The question marks for the Delaware and Maryland sites note that it has not been confirmed that Drosera filiformis has ever occurred as a native at these locations. 
New J ersey: Records include M onmouth, Ocean, Burlington, Camden, A tlantic, and Cape M ay Counties.

Maryland: It occurs in Charles County, and a non-native population has al so been found in Prince Georges County (Shetler \& O rli 2000; Sorrie 1998). The non-native planting casts some doubt upon the nativity of the Charles County site, but there is no certainty in this matter.

Delaware: Fernald (1931) indicated the presence of D. filiformis in Sussex County, but no voucher specimens have been found to support this claim (Sorrie 1998).

\section{Carolinas R ange Segment}

North C arolina: It has been recorded from Bladen, B runswick, Columbus, Duplin, Pender, Robeson, and Sampson Counties (N atureServe 2008; Sorrie 1998). It is apparently extinct in B runswick and Pender Counties, and statewide has been reduced to as few as nine populations (Buchanan \& Finnegan 2008; Sorrie 1998). B ecause of its rarity, the N orth Carolina Natural Heritage Program classifies it as a plant of "special concern," and recommends this status be elevated to "significantly rare" (B uchanan \& Finnegan 2008).

South C arolina: Despite frequent reports of D. filiformis in South Carolina, no vouchers for the plant from this state have been located, nor is it recorded in regional surveys or Heritage databases (Schnell 2002; Sorrie 1998).

\section{Florida Segment}

Florida: K nown from a cluster of sites in the Florida panhandle, as originally identified by Godfrey (1974). Currently, I know of two sites in B ay County and ten sites in Washington County. These sites are so close that they are easily connected by pollinating insects; no doubt propagules such as seed can be transported from site to site by waterfowl or even flooding. A single collection of a thread-leaf sundew from Liberty County (A palachicola National Forest) was made in 1987 (A nderson 10436 FSU) with the notation "Iess robust than D. tracyi". Despite the small stature of this collection, other morphometric criteria indicate this collection is probably $D$. tracyi (Rice, in prep.). I returned to this site in 2010 but was unsuccessful in finding any thread-leaf sundews- woody vegetation had overgrown the area. Even if $D$. filiformis is found in this area, its nativity would be questionable since horticul turists have used various parts of A palachicola as a dumping ground for non-native carnivorous plants.

Other sites: In addition to the questionably non-native population in M aryland, mentioned above, D. filiformis has been planted by horticulturists in numerous places, including California (M endocino County: Rice 2002), Virginia (Caroline County: pers. observation), and West Virginia (Preston County: B reiding 1983; Sorrie 1998). D rosera filiformis has been collected in Pennsylvania (Fayette County: M orton \& Speedy 2008), but the southern border of Fayette county is only $20 \mathrm{~km}$ from the West Virginia site, and so it is likely that the Pennsylvania record simply is another exotic planting. A single non-native planting of $D$. xhybrida ( $=$ D. filiformis $x$ intermedia) was recorded in California (Plumas County: Rice 2005) but it has probably been successfully eradicated. No doubt exotic plantings of thread-leaf sundews occur el sewhere in North A merican and around the world.

As seen in Figures 1 and 2, the ranges of the two species are dramatically different. The tiny amount of overlap region in Florida is not significant in light of the other, vastly greater differences. Interestingly, Sorrie (1998) notes that the pairing of two species, one being from the Gulf Coast and the other from the A tlantic Coast, is not unique to the thread-leaf sundews. This sort of pairing is repeated within other genera, i.e., Sabatia kennedyana Fern. (N ova Scotia to South Carolina) and S. foliosa Fern. (South Carolina to Texas); Coreopsis rosea N utt. (Nova Scotia to Georgia) and C. nudata Nutt. (Georgia to L ouisiana). To this, we can add Sarracenia purpurea L. (Canada to Georgia) and S. rosea Naczi, Case \& Case (Georgia to M ississippi). 


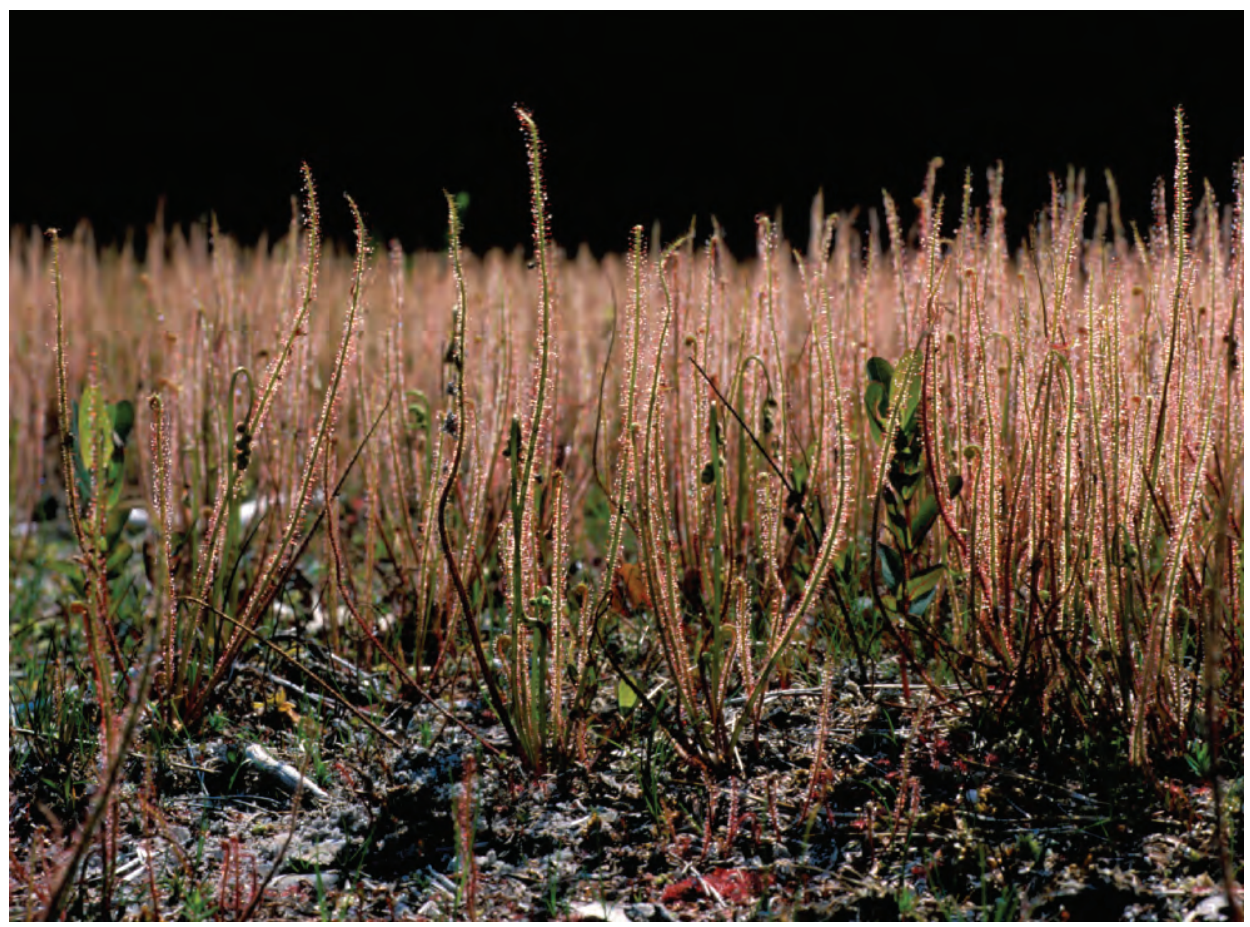

Figure 3: Drosera filiformis growing on sandy flats in New Jersey (Ocean County).

M erge or split the thread-leaf sundews?

Should Drosera filiformis and D. tracyi be treated as two species, as two varieties, or even with no taxonomic recognition, as described near the beginning of this paper? The main points of discussion are three:

1) The two taxa are not particularly different on vegetative or floral characters;

2) The seeds of the two taxa are, essentially, identical;

3) Hybrids between the two species are possible and recorded in the wild (Rice 2010); furthermore they are fertile.

Can the two taxa easily be separated on gross morphological grounds? Clearly the plants have different pigmentations. A s reviewed in Table 1 (from Sorrie 1998), D. filiformis is more deeply pigmented (Figure 3; reddish leaves, reddish tentacles, red gland heads) than D. tracyi (Figure 4; green leaves, green-white tentacles, red gland heads). B ut basing species distinctions on minor matters like pigmentation is inadequate. For example, it resulted in the erroneous separation of $D$. brevifolia Pursh into the white flowered "D. leucantha Shinners" and the pink-flowered "D. annua Reed" (Schnell 2002).

Further important characters that distinguish the two taxa are given in Table 1. In Tables 2 and 3, I present additional data from my own studies-Table 2 contains characters showing the entire range of values observed, while Table 3 shows the ranges as calculated by one-sigma variations around the group averages ${ }^{2}$. Some of the characters may not seem significantly different between the two

\footnotetext{
${ }^{2}$ The one-sigma range is a statistical measure; it contains about $68.2 \%$ of the values you are likely to encounter in a sample, and is a good way to specify the range of values you are likely to get when you measure a quantity.
} 


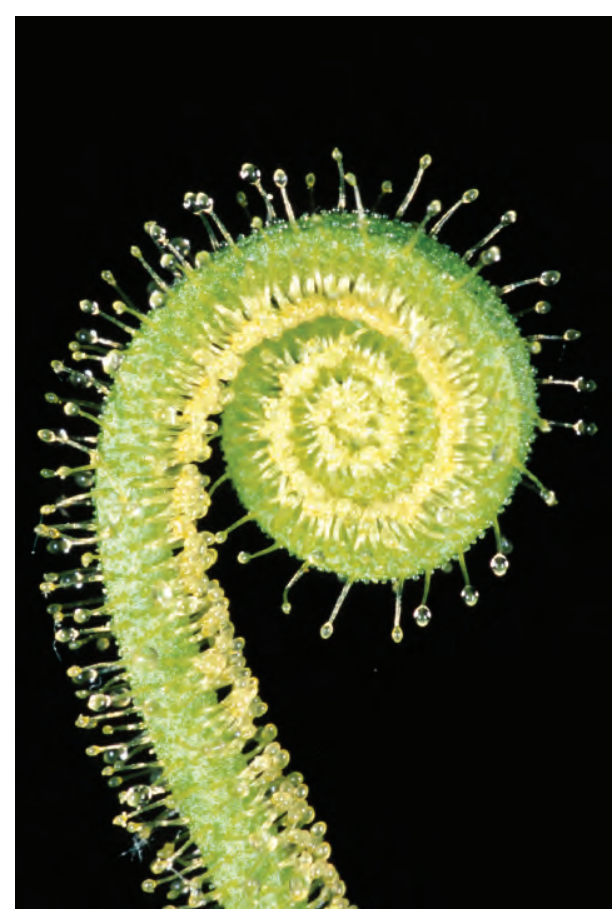

Figure 4: A close view of an unfurling leaf of Drosera tracyi.

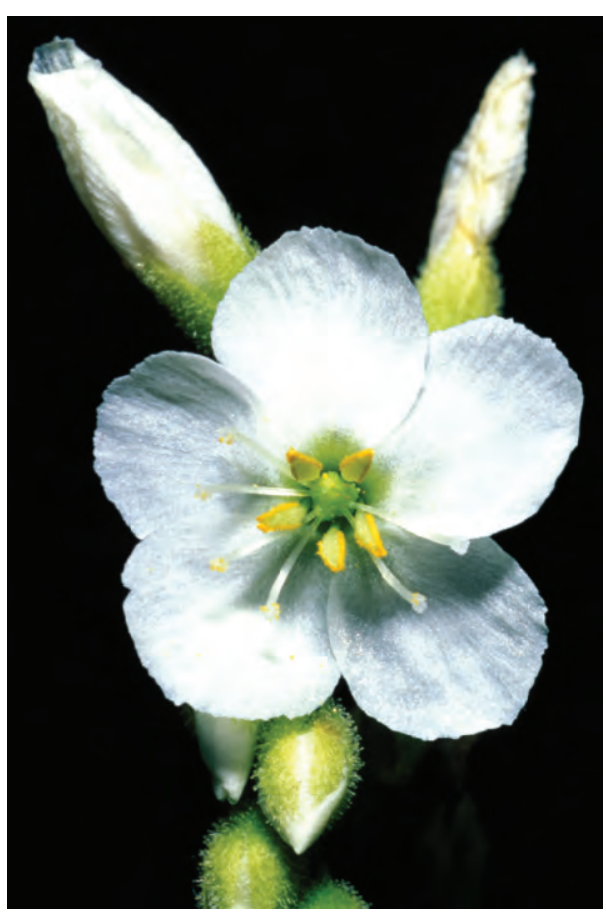

Figure 5: The white-flowering, mutant form of Drosera tracyi.

species when you consider the total ranges shown in Table 2- for example the number of flowers per inflorescence can range from 4 to 21 for $D$. filiformis and 12 to 20 for $D$. tracyi. The overlap here is significant, but the one-sigma ranges in Table 3 do differ much more clearly, i.e., 7-15 for D. filiformis and 13-19 for D. tracyi.

It is interesting that the tentacles of $D$. filiformis are longer than those of $D$. tracyi. The differences are particularly clear when normalized by the leaf width. The tentacle length/leaf width is $2.6-4.8$ for $D$. filiformis and 0.9-2.3 for $D$. tracyi. N otice that, in this case, the smaller plant has the largest tentacles.

Similarly, the relative geometry of the leaves, expressed by the ratio of the total leaf length divided by petiole length is different for the two species: 18-110 for $D$. filiformis and 5.1-25 for D. tracyi.

\begin{tabular}{|l|l|l|}
\hline \multicolumn{3}{|l|}{ Table 1: Characters used to distinguish Drosera filiformis and D. tracyi. ${ }^{1}$} \\
\hline Character & D rosera filiformis & D rosera tracyi \\
\hline L eaf length & $8-25(30) \mathrm{cm}$ & $30-50 \mathrm{~cm}$ \\
\hline Scape length & $6-26 \mathrm{~cm}$ & $25-60 \mathrm{~cm}$ \\
\hline Petal length & $0.7-1(1.2) \mathrm{cm}$ & $1.2-1.7(2) \mathrm{cm}$ \\
\hline Color of carnivorous glandular hairs & red to dark red & pale green \\
\hline Color of living plant when backlit & reddish & white \\
\hline Color of dried specimen & dark red to dark brown & pale greenish brown \\
\hline${ }^{1}$ Data from Sorrie (1998). & & \\
\hline
\end{tabular}




\begin{tabular}{|c|c|c|}
\hline \multirow[t]{2}{*}{ Character } & D rosera filiformis & D rosera tracyi \\
\hline & total range & total range \\
\hline L eaf length & $6-25 \mathrm{~cm}$ & $24-34.5 \mathrm{~cm}$ \\
\hline Petiole length ${ }^{2}$ & $1-16 \mathrm{~mm}$ & 6-70 mm \\
\hline Scape length & $7.8-25 \mathrm{~cm}$ & $28-47 \mathrm{~cm}$ \\
\hline \# of flowers & $4-21$ & $12-20$ \\
\hline Tentacle length ${ }^{3}$ & $0.7-3.2 \mathrm{~mm}$ & $0.8-2.5 \mathrm{~mm}$ \\
\hline Tentacle/leaf width & $1.3-6.7$ & $0.7-3.8$ \\
\hline L eaf/petiole & $9.9-170$ & $4.5-53$ \\
\hline \multicolumn{3}{|c|}{$\begin{array}{l}{ }^{1} \text { Original data. } \\
{ }^{2} \text { The petiole is the nonglandular portion of the leaf, near the basal bud. } \\
{ }^{3} \text { b btained by measuring the longest tentacles (including gland tip) near leaf midpoint (half-way up the leaf), avoiding } \\
\text { tentacles that were obviously damaged or distorted by the preservation process. }\end{array}$} \\
\hline
\end{tabular}

In summary, I believe the data in Tables 1-3 support species recognition because the differences between $D$. filiformis and $D$. tracyi are not restricted to one or two characters. A t least four independent characters are different: size of vegetative parts (leaves), size of flowers, leaf coloration, and the relative dimensions as expressed by tentacle/leaf and leaf/petiole ratios.

Ironically, the fact that the thread-leaf sundews are so different from other D rosera contributes to their being interpreted as a single species. The only other species in the genus even remotely similar in form is the South A merican D. graminifolia St. Hil. A s a result, the differences between D. filiformis and D. tracyi seem less significant, when in fact they are considerable.

The second argument about the thread-leaf sundews is the observation that, in N orth A merica, all the $D$ rosera species have seeds that are uniquely identifiable under a microscope (Wynne 1944). Shape and surface ornamentation allow for easy identification of every N orth A merica species. However, the thread-leaf species cannot be distinguished from each other on the basis of seed characteristics.

\begin{tabular}{|c|c|c|}
\hline \multirow[t]{2}{*}{ Character } & D rosera filiformis & D rosera tracyi \\
\hline & $($ ave- $1 \sigma)-($ ave $+1 \sigma)$ & $($ ave- $1 \sigma)-($ ave $+1 \sigma)$ \\
\hline L eaf length & $9.7-17 \mathrm{~cm}$ & $26-32 \mathrm{~cm}$ \\
\hline Petiole length ${ }^{2}$ & $0-9 \mathrm{~mm}$ & $11-44 \mathrm{~mm}$ \\
\hline Scape length & $8.9-19 \mathrm{~cm}$ & $31-45 \mathrm{~cm}$ \\
\hline \# of flowers & $7-15$ & $13-19$ \\
\hline Tentacle length ${ }^{3}$ & $1.3-2.4 \mathrm{~mm}$ & $1.0-1.8$ \\
\hline Tentacle/leaf width & $2.6-4.8$ & $0.9-2.3$ \\
\hline L eaf/petiole & $18-110$ & $5.1-25$ \\
\hline \multicolumn{3}{|c|}{$\begin{array}{l}{ }^{1} \text { Original data. } \\
{ }^{2} \text { The petiole is the nonglandular portion of the leaf, near the basal bud. } \\
{ }^{3} \text { btained by measuring the longest typical tentacles (including gland tip) near leaf midpoint (half-way up the leaf), avoiding } \\
\text { tentacles that were obviously damaged or distorted by the preservation process. }\end{array}$} \\
\hline
\end{tabular}


This fact is undeniable, but is it significant? Elsewhere in the genus, seed coat is used only rarely to key species (Diels 1906; L owrie 1987, 1989; Schlauer 1996). Perhaps one might devise a key based solely upon seed characteristics, but this is purely speculative. I argue that while it is undeniable that seed coats are distinct for most of the various species present in N orth A merica, it simply does not work for them all. In the same way, stipule characteristics can be used to identify many of the North A merican D rosera, but not all of them. Indeed, it is a very rare case that one encounters a botanical key that relies exclusively on one character. The fact that seed coats are different for many species of D rosera in North A merica is a useful and convenient tool in identification, but there is little evidence that it is a strong diagnostic for species variation across the genus, or even within section D rosera.

The final argument that these species should be lumped is based upon the observation that the two species can be hybridized, and the resulting progeny are fertile (Robinson 1981). Fertile hybrids between D. filiformis and D. tracyi have even been observed at a single site in the wild (Rice 2010). This is a powerful observation, and must be addressed completely.

A s is commonly taught in school, interspecies infertility is a robust method of identifying separate species of vertebrate animals. But this metric is not as reliable in the plant world. Carnivorous plant enthusiasts are familiar with the fact that wild and cultivated fertile hybrids are common in Heliamphora, Nepenthes, and Sarracenia (Clarke; M cPherson 2007; Rice 2006). Elsewhere in the wild and in horticulture, fertile hybrids are common in grapes, oaks, roses, tamarisk, violets, and countless other plant groups (M abberley 1997). In some cases it is even possible to cross plants of different genera, resulting in fertile hybrid genera such as XTriticosecale (=Triticum $\times$ Secale), XF atshedera ( $=$ Fatsia $\times$ Hedera), or even bizarre multigenera orchid hybrids such as $\times B$ rilliandeara (= Aspasia $\times$ Brassia $\times$ Cochlioda $\times$ Miltonia $\times 0$ dontoglossum $\times 0$ ncidium).

Interspecific hybrids are frequent within D rosera. In horticulture, enthusiasts have produced the fertile hybrids $D$. anglica $\times$ nagamotoi, D. burmannii $\times$ sessilifolia, and $D$. dielsiana $\times$ nidiformis (Snyder 2000), and many others.

D rosera hybrids also occur in the wild. All the species in section Lasiocephala (i.e., the "petiolaris complex") hybridize in the wild and in cultivation (L owrie 1999). A dditionally, natural populations of D. x sidjamesii (=D. omissa x pulchella) have developed fertile, seed-setting plants (L owrie \& Conran 2007). Within section D rosera, hybrids are frequent; not only are they fertile in the case of the thread-leaf sundews, but fertile first-generation crosses have been observed involving Zambian species (Rivadavia, pers. comm., 2010). Natural hybrids such as D. rotundifolia $x$ linearis and $D$. rotundifolia $x$ spatulata are sterile in their first generation, but can apparently become fertile in subsequent populations via natural chromosome doubling, thus establishing D. anglica and D. tokaiensis, respectively (Schlauer 2010; Seno 2003).

Does interfertility mean the two thread-leaf sundews are the same species? I do not think so, but I believe that it indicates that the speciation (separation of the two species) is probably recent-Sorrie (1998) speculates that ancestral propagules of D. filiformis migrated northwards out of Florida after the Pleistocene (e.g., approximately 12,000 years before present). It is currently a matter of pure speculation as to whether one species evolved from an ancient population of the other, or they both speciated from a common ancestor, or some other scenario.

There are many philosophies on what defines a species. I follow the traditional biological species concept, which is that "species are groups of actually or potentially interbreeding natural populations that are reproductively isolated from other such groups" (M ayr 1942). In the case of the thread-leaf sundews, we have two significantly morphologically different populations of plants, which occupy different ranges (and different habitat types within those ranges), and which are- for the most part- not exchanging genetic material. They are, simply, two different species. Those with 


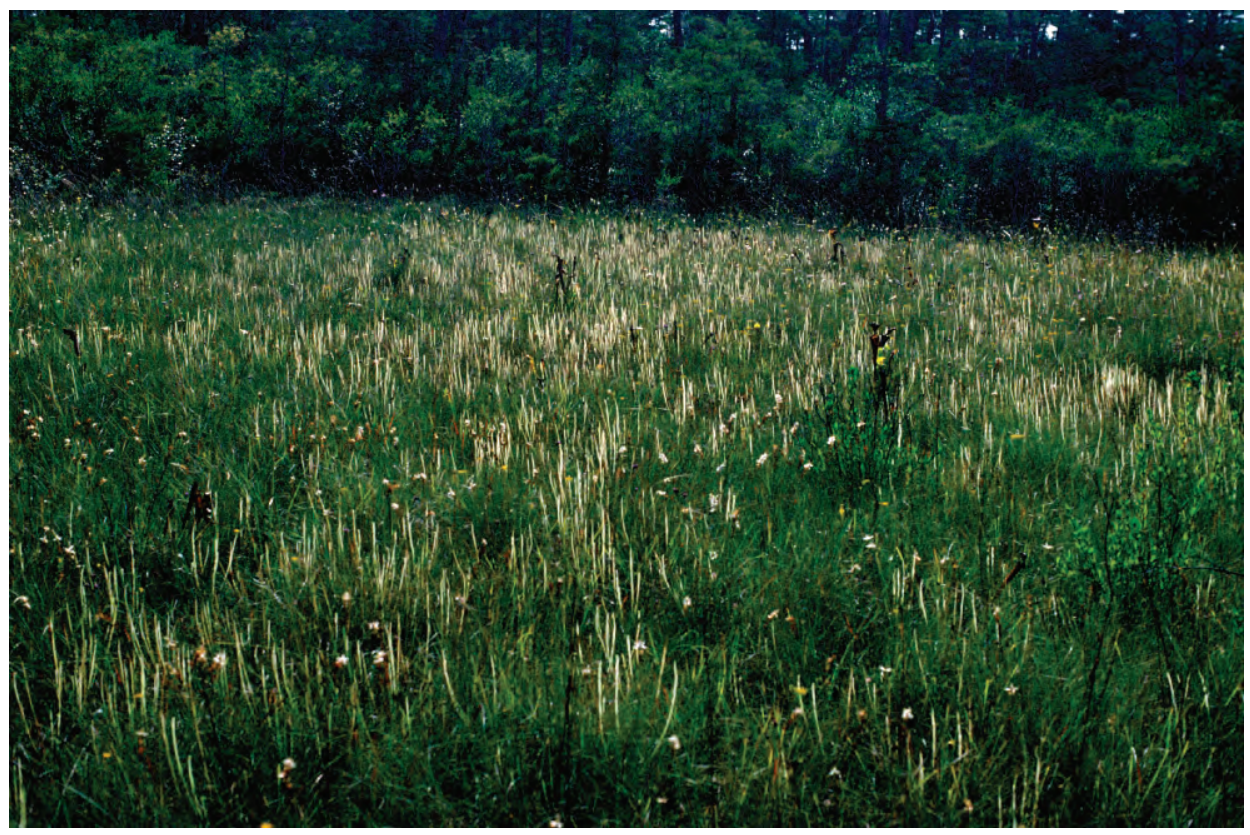

Figure 6: A familiar view of Drosera tracyi, backlit in the evening sunset (Liberty County, Florida).

different species concepts may come to different conclusions, and I do not fool myself into thinking I have had the last word on the subject of the two thread-leaf sundews. A s Peter Taylor (1989) wrote, "Nothing is perfect, except perhaps the plants that we study and attempt to understand... ."

Varieties, subspecies, or forms of thread-leaf sundews?

There are no infraspecific taxa identified for $D$. tracyi- the species is uniform in characteristics over its entire range. The only known variant is an anthocyanin-free specimen (see Figure 5) collected in Franklin County, Florida (Hummer 1998); this plant's novel mutation is expressed by its having white flowers and carnivorous gland-heads that are green instead of red. A name for this plant might be established at the rank of "forma," much like the analogous case with Sarracenia rosea f. luteola. However, current thought in botany is that names are best given to populations of plants that are evolutionary units: species, subspecies, and varieties. The "forma" rank is no longer considered of particular value. On the other hand, since such minor differences are appreciated by horticulturists, they can be named as cultivars, much like the green-flowered Darlingtonia californica has been named Darlingtonia 'Othello.'

Drosera filiformis is a distinctly different beast, however, since its range is fragmented into four separate populations, each of which may have developed different characteristics. In particular, carnivorous plant enthusiasts would very much like to hear of a new designation for the Floridian populations. I have been investigating this matter for several years, but a pronouncement al ong such lines would currently be premature and scientifically sloppy. I hope to settle this matter to my own satisfaction as soon as possible, but careful research efforts (herbarium loans, morphometric measurements, analyses, etc.) take time to conduct. U ntil the time that I feel comfortable publishing my 
results, I recommend that horticulturists carefully maintain location information for their beloved plants, and strive to be patient!

Acknowledgments: I would like to thank Ellen Dean and J ean Shepard at the Center for Plant Diversity (University of California, Davis), for their continual support, especially in processing my requests for herbarium loans. Fernando Rivadavia provided useful perspectives and comments in reviewing drafts of this paper.

\section{References}

BONA P. 2010. The Biota of N orth A merica Program. B ONA P.org, accessed 5 J uly 2010.

B reiding, M . 1983. Two D rosera (sundew) species new to West Virginia. Castanea 48:55.

Buchanan, M.F., and Finnegan, J.T. 2008. Natural Heritage Program list of rare plant species of North Carolina, 2008. North Carolina N atural Heritage Program. Ral eigh, N orth Carolina.

Clarke, C. 1997. Nepenthes of B orneo. N atural History Publications, K ota K inabalu, XI+ 207 pp.

Clewell, A.F. 1985. Guide to the vascular plants of the Florida Panhandle. University Presses of Florida, Tallahassee, Florida, $605 \mathrm{pp}$.

COSEWIC. 1991. Canadian species at risk. Committee on the Status of Endangered Wildlife in Canada. Canadian M useum of Nature, Ottawa, Ontario.

Diels, L. 1906. N o. 112. Droseraceae. In: A. Engler, ed. Das Pflanzenreich. IV. Weinheim, Germany. Enser, R.W. 2007. Rare native plants of Rhode Island. Rhode Island Natural Heritage Program, Providence, Rhode Island. (http://www.dem.ri.gov/programs/bpoladm/plandev/heritage/)

Fernald, M .S. 1931. Specific segregates and identities in some floras of eastern N orth A merica and the Old World. Rhodora 33: 53-55.

Gleason, H.A., and Cronquist, A. 1991. M anual of the vascular plants of northeastern U nited States and adjacent Canada, 2nd Ed. The N ew York B otanical Garden, B ronx, N ew York, 910 pp.

Godfrey, R.K. 1974. D rosera filiformis Raf. in Florida. Carniv. PI. N ewslett. 3:51.

Godfrey, R.K., and Wooten, J.W. 1981. A quatic and wetland plants of Southeastern U nited States:

Dicotyledons. The U niversity of Georgia Press, A thens, Georgia, 933 pp.

Hummer, J.H. 1998. A noteworthy Florida find: D rosera filiformis var. tracyi (Droseraceae). Carniv. PI. Newslett. 27:89-90.

Kartesz, J.T. 1994. Synonymized checklist of vascular flora of the United States, Canada, and Greenland, 2nd ed. 2 vols. Timber Press, Portland, Oregon, 1438 pp.

L NHP. 2009. Rare Plant Tracking List, January 2009. L ouisiana N atural Heritage Program.

Landry, M ., and Cwynar, L.C. 2005. History of the endangered D rosera filiformis, thread-leaved sundew, in southern Nova Scotia. Can. J. Bot. 83: 14-21.

Lowrie, A. 1987. Carnivorous Plants of A ustralia, Vol I. University of Western Australia Press, XXVI+202 pp.

Lowrie, A. 1989. Carnivorous Plants of A ustralia, Vol II. University of Western A ustralia Press, XXXVIII+202 pp.

Lowrie, A. 1999. Carnivorous Plants of A ustralia, Vol III. University of Western A ustralia Press, $288 \mathrm{pp}$.

Lowrie, A., and Conran, J.C. 2007. D rosera xsidjamesii (D roseraceae): systematics and ecology of a natural hybrid from Western A ustralia. A ustralian Systematic B otany 20: 44-53.

M abberley, D.J. 1997. The Plant B ook. Cambridge U niversity Press. Cambridge. 858 pp.

M acfarlane, J.M. 1914, Drosera. In: L.H. B ailey, ed. The Standard Cyclopedia of H orticulture, Vol. 1 (page 1077). N ew York, N ew York. 
M ayr, E. 1942. Systematics and the origin of species. Columbia U niv. Press, N ew York, 372 pp.

M cPherson, S. 2007. Pitcher Plants of the A mericas. The M cDonald \& Woodward Publishing Company. Blackburg, Virginia, and Granville. VIII+ 320 pp.

M orton, C.M ., and Speedy, L . 2008. Checklist of the vascular plants of Fayette County, Pennsylvania. J. B ot. Res. Inst. Texas 2: 1449-1474.

NatureServe. 2008. N atureServe Explorer, D rosera tracyi/D rosera filiformis. http://www.natureserve.org, accessed 5 July 2010.

NSSRW G. 2000. Species at risk list regulations, N ova Scotia Species at Risk Working Group. Government of Nova Scotia, Halifax. NS.

Rice, B.A ., 2002. Drosera aliciae, D. capensis, and U tricularia subulata in California (N oteworthy Collections), M adroño 49: 193-194.

Rice, B.A., 2005. D rosera xhybrida in California (N oteworthy Collections), M adroño 52: 271-272.

Rice, B.A. 2006, Growing Carnivorous Plants. Timber Press, Portland, Oregon, 225p.

Rice, B.A. 2010. Noteworthy collections: Florida. Carniv. PI. N ewslett. 39: 91.

Rivadavia, F., Kondo, K., K ato, M., and Hasebe, M. 2003. Phylogeny of the sundews, Drosera (D roseraceae), based on chloroplast $\mathrm{rbcL}$ and nuclear $18 \mathrm{~S}$ ribosomal DNA sequences. A m. J. B ot. 90: 123-130.

Robinson, J.T. 1981. New cultivars: Drosera filiformis 'California Sunset'. Carniv. PI. Newslett. 10: 95.

Schnell, D.E. 2002. Carnivorous Plants of the U nited States and Canada, 2nd ed. Timber Press, Portland, Oregon.

Schlauer, J. 1996. A Dichotomous K ey to the G enus D rosera L. (D roseraceae). Carniv. PI. N ewsl ett. 25:67-88.

Schlauer, J. 2002. World Carnivorous Plant List--Nomenclatural Synopsis of Carnivorous Phanerogamous Plants, http://www.omnisterra.com/bot/cp_home.cgi, accessed J une 2010.

Schlauer, J. 2010. N omenclature of the D rosera anglica complex revisited. Carniv. PI. N ewslett. 39:46. Seno, J. 2003. A new natural hybrid of Drosera (Droseraceae) from M iyazaki Prefecture, Southwestern Japan. J. Jap. Bot. 78:170-174.

Shetler, S.G., and Orli, S.S. 2000. A nnotated checklist of the vascular plants of the WashingtonB altimore area, Part I: Ferns, fern allies, gymnosperms, and dicotyledons. N ational M useum of Natural History. Smithsonian Institution, Washington, DC.

Sheviak, C.J. 2010. The roots of the herbarium. Legacy: The M agazine of the N ew York State M useum 5: 10-11.

Snyder, I. 2000. Colchicine treatment on sterile hybrid sundews. Carniv. PI. N ewslett. 29:4-10.

Sorrie, B.A. 1998. Distribution of Drosera filiformis and D. tracyi (Droseraceae): phytogeographic implications. Rhodora 100: 239-260.

Taylor, P. 1989. The genus U tricularia: a taxonomic monograph. Kew Bull. Add. Ser. 14:1-724.

USDA . 2010. The PLA NTS Database (http://plants.usda.gov, accessed 5 J uly 2010). N ational Plant Data Center, Baton Rouge, LA 70874-4490 USA.

Weakley, A.S. 2010. Flora of the Southern and M id-A tlantic States. U NC Herbarium. http://www. herbarium.unc.edu/flora.htm.

Wunderlin, R. P., and B. F. Hansen. 2008. A tlas of Florida Vascular Plants (http://www.plantatlas. usf.edu/, accessed 5 J uly 2010).

Wynne, F.E. 1944. D rosera in eastern N orth A merica. Bull. of the Torrey B ot. Club. 71: 166-174.

Young, S.M. (ed) 2010. N ew York rare plant status lists, New York Natural Heritage Program, A lbany, N ew York. (http://www.dec.ny.gov/animals/7135.html) 


\section{CARNIVOROUS PLANT NEWSLETTER}

Journal of the International Carnivorous Plant Society

\section{Volume 40, N 0.1}

\section{M arch 2011}

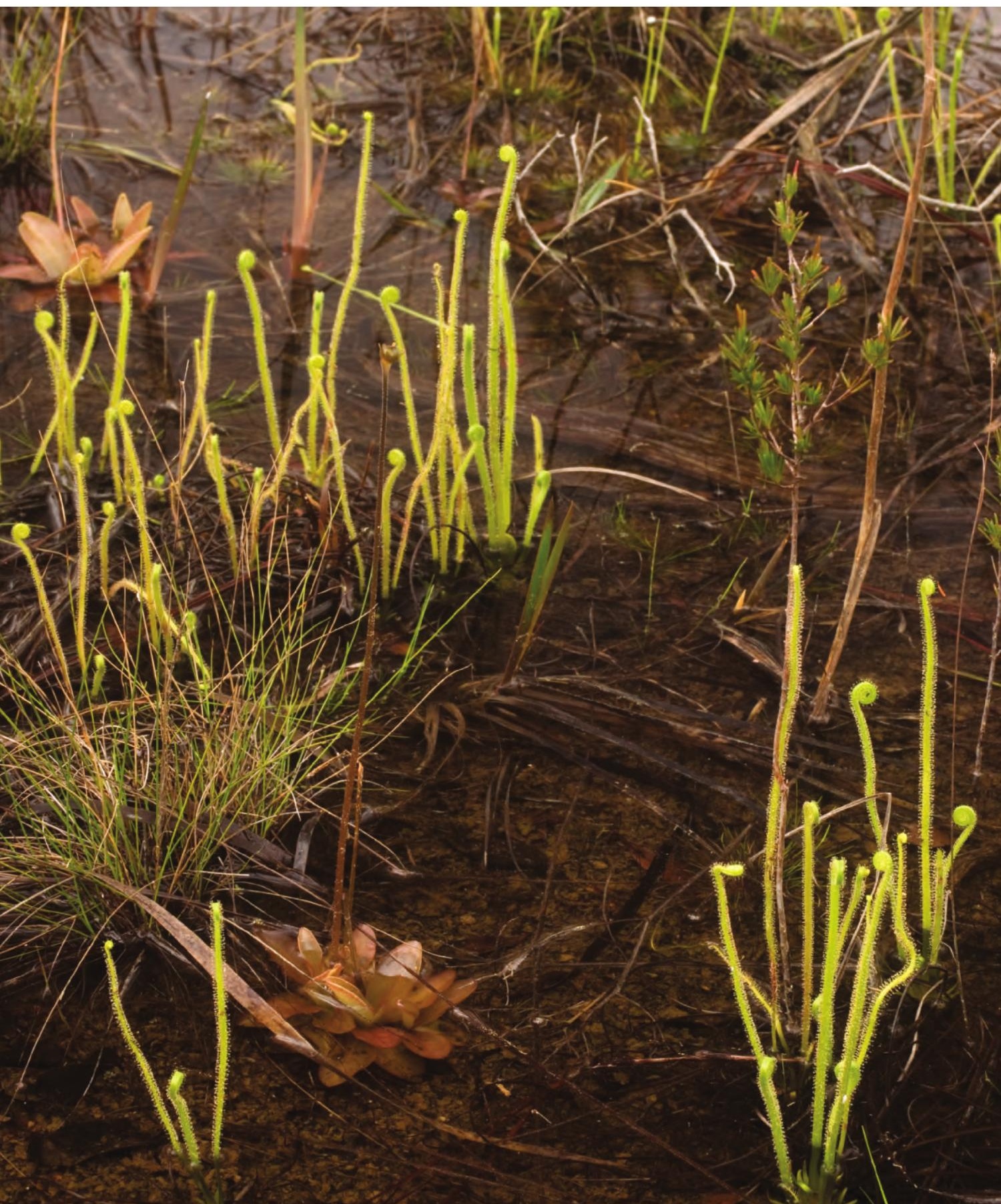




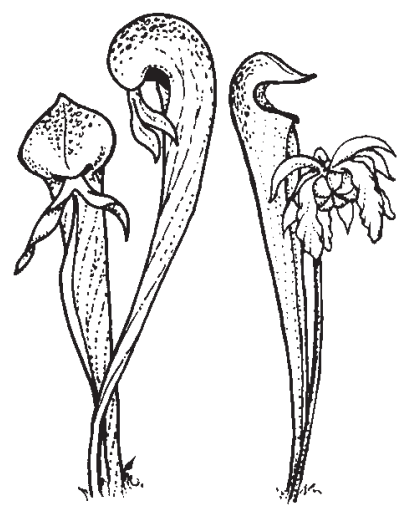

\section{CARNIVOROUS \\ PLANT \\ NEWSLETTER}

Journal of the International

Carnivorous Plant Society

www.carnivorousplants.org

\section{Volume 40, Number 1 March 2011}

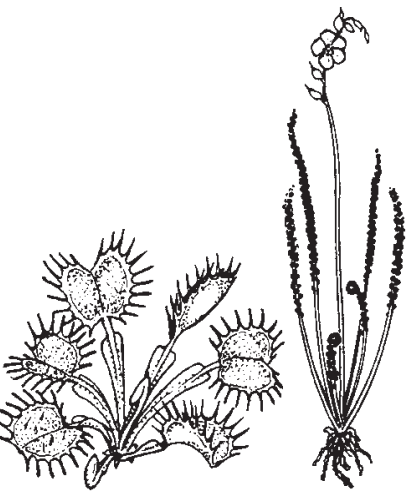

\section{Front Cover: Drosera tracyi growing with Pinguicula planifolia in temporarily flooded conditions; Apalachicola National Forest (Liberty County, Florida). Photo by Barry Rice. Article on page 4.}

Back Cover: The striking dark coloration of a dark color variant of the recently discovered Nepenthes leonardoi. Note the purple-colored exterior surface of the pitcher is lined with short, brown hairs. Photo by Stewart McPherson. Article on page 28.

Carnivorous Plant N ewsletter is dedicated to spreading knowledge and news related to carnivorous plants. Reader contributions are essential for this mission to be successful. Do not hesitate to contact the editors with information about your plants, conservation projects, field trips, or noteworthy events. A dvertisers should contact the editors. Views expressed in this publication are those of the authors, not the editorial staff.

All correspondence regarding dues, address changes and missing issues should be sent to the Membership Coordinator at the ICPS. Do not send such correspondence to the editors. Checks for subscriptions should be made to the ICPS in US funds. Dues for 2011 are \$35 for the first year of membership; renewals are $\$ 30$ per year.
ICPS, Inc.
PM B 322
1564-A Fitzgerald Drive
Pinole, CA 94564-2229, USA
icps@carnivorousplants.org

President Michael Baldwin, michael@ carnivorousplants.org

Vice President M Marcel van den Broek, marcel@ carnivorousplants.org

Secretary_ Cindy Slezak, cindy@ carnivorousplants.org

Treasurer

Richard M yers, richard@ carnivorousplants.org

B oard M ember Bob Ziemer, bob@carnivorousplants.org

B oard M ember Jan Schlauer, jan@ carnivorousplants.org

B oard M ember B B Bian Barnes, Conservation Director, brian@ carnivorousplants.org

Seed B ank M anager John B rittnacher, john@ carnivorousplants.org (see seed bank ad in this issue)

Editors:

M anaging Editor Bob Ziemer, bob@carnivorousplants.org

Science Editor Jan Schlauer, jan@ carnivorousplants.org

Science Editor Fernando Rivadavia, fernando@ carnivorousplants.org

Editor

Barry Rice, barry@ carnivorousplants.org

Date of effective publication of the December 2010 issue of Carnivorous Plant N ewsletter: 30 N ovember 2010.

The ICPS is the International Cultivar Registration A uthority (ICRA) for the names of cultivated carnivorous plants according to the International Code of Nomenclature for Cultivated Plants. Send relevant correspondence to the ICPS, Inc.

Carnivorous Plant Newsletter is published quarterly in M arch, June, September, and December by the ICPS, Inc. Periodicals postage pending at Richmond, $\mathrm{CA}$ and additional mailing offices. Postmaster: Send address changes to ICPS, Inc., PM B 322, 1564-A Fitzgerald Drive, Pinole, CA 94564-2229, USA. Printed by A llen Press, Inc., 810 E. 10 th Street, L awrence, K S 66044. L ogo and masthead art: Paul M ilauskas.

(c) 2011 Carnivorous Plant N ewsletter. All rights reserved. ISSN \#0190-9215 